\title{
Assessment of Radon in groundwater and associated human risk from Sankarabarani River Sub Basin, Southern India
}

\author{
A. Rajesh Kanna a, K. Srinivasamoorthy a,*, G. Ponnumani a, S. Gopinath a, R. Prakash a, \\ D. Karunanidhi b, F. Vinnarasai a \\ a Department of Earth Sciences, School of Physical, Chemical and Applied Sciences, Pondicherry University, Puducherry \\ 605 014, India \\ b Department of Civil Engineering, Sri Shakthi Institute of Engineering and Technology, Coimbatore, Tamil Nadu 641 062 \\ India.
}

*Corresponding Author moorthy_ks@yahoo.com (K. Srinivasamoorthy)

Received : 01 03 2019 Accepted : 17 04 2019

\begin{abstract}
Radon $\left.{ }^{222} \mathrm{Rn}\right)$ and associated human risk assessment in groundwater from quaternary shallow aquifers of Sankarabarani River sub basin, Southern India has been attempted by considering 41 groundwater samples and analysed for ${ }^{222} \mathrm{Rn}$ using scintillation Radon monitoring system. The Radon ranges between $0.140 \pm 0.01 \mathrm{~Bq}^{1^{-1}}$ to $7.869 \pm 0.33 \mathrm{~Bq} 1^{-1}$ with an average of $1.797 \pm 0.12 \mathrm{~Bq} 1^{-1}$ and found to be within the maximum contamination level of Environmental Protection Agency (11.1 Bq 1 $\left.{ }^{-1}\right)$. The doses of ingestion and inhalation calculated for radon varies between $0.709 \mu \mathrm{Sv}^{-1}$ to $39.933 \mu \mathrm{Sv}$ $\mathrm{y}^{-1}$ with an average of $9.121 \mu \mathrm{Sv} \mathrm{y}^{-1}$ which is within the prescribed dose limit of $100 \mu \mathrm{Sv} \mathrm{y}^{-1}$ by World Health Organisation. Uranium speciation attempted suggests saturated Haiweeite and Soddyite as sources for uranium/radon into the aquifer systems. The Eh $\sim \mathrm{pH}$ diagram suggests uraninite solubility within the $\mathrm{pH}$ ranges 6 to 8 within the groundwater environment.
\end{abstract}

Keywords: Ground water, sankarabarani river, Radon, ingestion and inhalation, uranium solubility,

\section{Introduction}

Humans are exposed to ionizing radiation occurring naturally in soil, water air and food and the most significant is the radio nuclides present in water that gets easily absorbed in comparison with food [1]. Groundwater in comparison with surface water is exposed to privileged radioactivity due to its interaction with aquifer materials that host minerals enriched with radioactive substances [2, 3]. Major radioactive elements hosted in aquifers are not limited to uranium, thorium and actinium, of which the uranium series are hazardous to health due to its existence in water as Radium $\left.{ }^{226} \mathrm{Ra}\right)$ and radon $\left.{ }^{222} \mathrm{Rn}\right)$ [4]. At ambient temperature and pressure radon is a noble gas which can be separated from its parent 226Ra. Radium 226 decays to Radon (half $\sim$ life $=3.82$ days) by alpha particle emission with $4.78 \mathrm{MeV}$ energy and with recoil energy of $86 \mathrm{KeV}$ [5] that emanates from the mineral grain surfaces and enters the aquifers. Radon in groundwater is generally higher due to rock weathering, restricted air borne dissolution and inflow from catchments with higher radon [6, 7], in view of surface water, lack of radon in precipitation and due to immediate diffusion to atmosphere its concentration is generally lower. The solubility of radon in water is lower with a partitioning coefficient of $0.23 \sim 0.25$ at $293 \mathrm{~K}$. Irrespective of its lower solubility its activity in water is higher in comparison with other natural radionuclide [3]. Due to non reactive nature of radon, the only loss from water column is by decay and atmospheric evasion [8].

Radon in groundwater seems to be influenced by climate, soil type and permeability, aquifer lithology and terrain [9]. Radon migrations in aquifer are mainly due to emanation and diffusion from sedimentary mineral grains containing uranium and radium [10] and its subsequent movement along the groundwater flow path. A strong disequilibrium exists between the source rocks and radon mobilisation due to geochemical condition that releases radon into waters. Aquifers with higher uranium might contain lower radon and vice versa which emphasis that radon in groundwater is controlled by low parental concentrations, porosity, stability of mineral structure and its crystallinity [11].

Radon by emission of alpha particle produce solid state daughter product called as radon progeny. Radon and its progeny are considered as health hazard when inhaled leading to lung cancer and ingestion leading to gastro - 
enteric cancers [12]. The [13] has estimated that $89 \%$ and $11 \%$ of cancer risks are mainly due to inhalation and ingestion of radon present in the environment. The maximum contamination level (MCL) of radon in drinking water has been suggested by united states environmental protection agency [14] as $148 \mathrm{~Bq} / \mathrm{L}$, World Health Organisation [15] as $100 \mathrm{~Bq} / \mathrm{L}$ and European Union [12] as $<100 \mathrm{~Bq} / \mathrm{L}$ and for India there is no reference level for radon in drinking water [16].

The aim of the present study is to evaluate the doses to population resulting from ingestion and inhalation of radon from groundwater in relation to health risk assessments. Investigation of radon distribution in groundwater in relation to different lithological and hydrological scenarios was also attempted. To our knowledge the present study is first of its kind in the coastal sedimentary environmental using radon as tracer to investigate health issues and geochemical signatures.

\section{Study Area}

The study area is Sankarabarani river basin located between latitudes $11^{\circ} 50^{\prime} \mathrm{N}$ to $12^{\circ} 05^{\prime} \mathrm{N}$ and longitudes $79^{\circ} 30^{\prime} \mathrm{E}$ to $79^{\circ} 50^{\prime} \mathrm{E}$ longitudes with a total spatial coverage of $506 \mathrm{Sq} . \mathrm{Km}$ that flows in the Villupuram district and Pondicherry union territory of Southern India (Fig.1). The river originates at the western slopes of Gingee Hill in Villuppuram District, Tamilnadu, India and finally configures Bay of Bengal at Pondicherry. The area experiences humid to tropical climatic condition with annual temperature ranges between $22^{\circ} \mathrm{C}$ to $33^{\circ} \mathrm{C}$ with relative humidity observed between $70 \%$ and $80 \%$. The annual rainfall is about $1272 \mathrm{~mm}$ with maximum showers during northeast monsoon (October December). The average elevation of the study area is of $15 \mathrm{~m}$ AMSL with gradual decrease towards the sea [17].

The geology of the study area can be divided into a series of north south trending belts (Fig.1) with majority of the area occupied by porous sedimentary formations representing Cretaceous to Recent. A small portion encompassed by fissured and fractured crystalline formations representing Archaean with litho units Charnockites and biotite hornblende gneiss that characterize the basement of Mesozoic and tertiary sediments are noted along the north western parts of the study area. Groundwater occurs under phreatic conditions in weathered and in semi confined condition in fissured and fractured formations with yield ranging between 6 to $30 \mathrm{~m}^{3}$ /hour [18]. The cretaceous are classified into four formations viz. Ramanathapuram formation (RF), vanur sandstone (VS), ottai claystone (OC) and thuruvai limestones (TL). RF and VS are essentially composed of sands and calcareous sandstones that are coarse grained, with veins of aragonite and thin intercalation of grey shales. The water occurs under confined condition with yield ranging between 48 to $90 \mathrm{~m}^{3} /$ day. The
OC is essentially composed of black to greenish grey clay stone with bands of limestone, silts and siltstones. The TL consists of fossiliferous limestone with bands of sandstones. Groundwater is found mainly in bands with yield ranging between 60.9 to $132.6 \mathrm{~m}^{3}$ /day. The paleocene is represented by kadaperikuppam (KK) and manaveli (MV) formations and the upper tertiary is represented by cuddalore (CU) formation isolated as small patches along northern parts of the study area trending North East $\sim$ South West. The KK encompasses litho units predominantly of calcareous sandstone, lenses of clay and shale with limestone bands. The MV contains litho units marked by sandy clay, shale and bands of limestone. The CU comprises coarse grained sandstones with minor clays, lignite and petrified wood. The yields from the well ranges between 12 to $180 \mathrm{~m}^{3} /$ day. Recent alluvium (Quaternary formation) the major exposure of the study area is essentially made up of gravel, sand, silt, clay and kankar. It forms the potential aquifers of the study area with thickness ranging between 5.0 to $34 \mathrm{~m}$. The groundwater occurs under water table or semi confined conditions with yield ranging between 0.6 to $147.6 \mathrm{~m}^{3} /$ day [18].

Various investigations globally have reported the radon levels in groundwater from aquifers. [19] has quantified the dissolved radon in aquifers of Algeria and Tunisia and found to be in radio equilibrium with rocks uranium content. Analysis of radon in different aquifers of Karnataka, India has been attempted by [20] and reported radon ranges between $0.37 \pm 0.05 \mathrm{~Bq} / 1$ to $87.02 \pm 2.11$ $\mathrm{Bq} / 1$ influenced by seasonal variations. [21] Studied about the radon emanation in Poland groundwater and isolated emanation coefficient influenced by rock tectonics. A study attempted by [22] in Chitradurga, Karnataka state, India to quantify radon in groundwater with respect to litho units and dose exposure suggests radon activity ranging between 0 to $186.6 \mathrm{~Bq} / \mathrm{L}$ and $\mathrm{O}$ to $150.6 \mathrm{~Bq} / \mathrm{L}$ during pre and post monsoon seasons and found to be exceeding the EPA's maximum contamination limit. [16] measured radon in drinking water samples from Haryana, India and observed radon ranging between $1.3 \pm 0.4$ and $13.4 \pm 2.2 \mathrm{~Bq}^{1^{-1}}$ and isolated locations with exceeded radon as recommended by USEPA. Radium and radon activities were assessed in southern Californian groundwater by [23] and suggested that distribution of $\mathrm{Rn}$ and $\mathrm{Ra}$ in groundwater influenced by cation exchange capacity of the aquifer materials. [24] attempted for radium and radon occurrence in groundwater from crystalline bed rocks from North Carolina, USA suggests $\mathrm{U}$ and $\mathrm{Th}$ in rocks control the occurrence along with secondary influence due to dissolved solids and redox conditions. Similar studies were attempted by [25].

\section{Sampling and experimental Methods}

Groundwater sampling for the radio isotopes have been attempted in bore wells and hand pumps mainly utilised for 

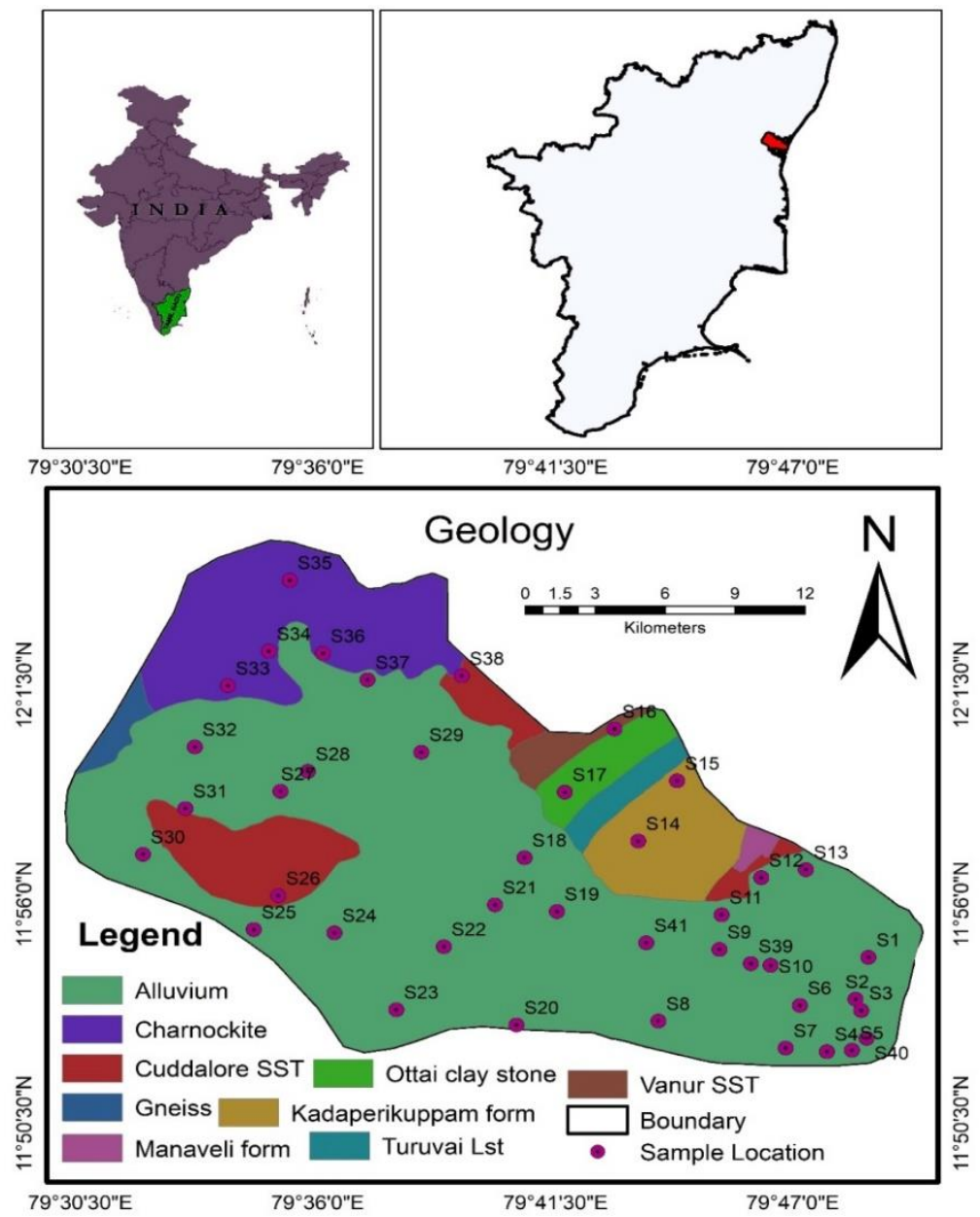

Fig 1. Location, Geology and sampling points of the study area

Five bore wells were sampled from Charnockite formations, two from cuddalore formations, two from kadaperikuppam, two from ootai limestone and forty samples from alluvial formations. Restricted samples confined to other formations except Alluvium due to non availability of wells (Fig.1). The depths of hand pump sampled were $\pm 50 \mathrm{Ft}$ and bore wells exceeded $\pm 150 \mathrm{Ft}$ Below Ground Level (BGL). Groundwater samples were collected in pre $15 \% \mathrm{HNO}_{3}$ and double distilled water washed samples bottles after purging water for about 10 to 15 minutes from the sampling wells. Groundwater samples were completely filled up to the zero without any air bubbles to prevent radon out gassing. The samples were immediately brought to the hydrogeology laboratory, Department of Earth Sciences, Pondicherry University within minimal less of time and analysed for radon. Radon in groundwater samples were measured by bubbling radon gas into $\mathrm{ZnS}(\mathrm{Ag})$ scintillator (Lucas cell) which detects and counts the photons generated due to the interaction of alpha particles resulting from radon decay inside the Lucas cell. The equipment used was the scintillation counter supplied by Polletec Instruments Pvt. Ltd., Mumbai that has been prior calibrated at Bhaba Atomic Research Centre, Mumbai, India with minimum detection limit of $0.05 \mathrm{~Bq} \mathrm{1}^{-1}$. The physical parameters like $\mathrm{pH}$, Eh, conductivity, Salinity, DO and TDS were measured in the field by using portable field kit (multi probe meter) ; Calcium $\left(\mathrm{Ca}^{2+}\right)$ and magnesium $\left(\mathrm{Mg}^{2+}\right)$ were determined titrimetrically using standard EDTA; Sodium $(\mathrm{Na}+)$ and Potassium $(\mathrm{K}+)$ were analysed by flame photometer (Systronics mk III)[26].

About $70 \mathrm{ml}$ of water is taken to the radon bubbler by vacuum transfer techniques. The radon gas dissolved in groundwater is acquired in pre evacuated $\mathrm{ZnS}(\mathrm{Ag})$ scintillation cell. Lucas scintillation cell is used for the estimation of radon [27] which was initially invented by [28] and modified by [29] and [4]. Lucas cell is a cylindrical container of $150 \mathrm{cc}$ volume built in with a Swagelok [quick] connector on one side for evacuation and sampling, and a glass window on the other side for counting activities of ${ }^{222} \mathrm{Rn}$. The wall of the cell is coated with Ag activated ZnS, which produces scintillation when alpha radiation emitted by radon and allied products. To attain equilibrium with daughters the scintillation cell is kept for $180 \mathrm{~min}$ without disturbance. These scintillations pass through the glass window and fall on the photocathode of a photomultiplier when couwepled to photomultiplier assembly. The cell can be used for repeated sampling by flushing it. The radon 
activity in groundwater calculated from the count by using the equation suggested by [30].

${ }^{222} \mathrm{Rn}\left(\mathrm{Bq} \mathrm{L}{ }^{-1}\right)=\frac{6.97 \times 10^{-2} \times D}{V \times E \times\left(1-e^{-\lambda t}\right) \times e^{-\lambda T}}$

where, $\mathrm{D}$ signifies the background count, $\lambda$ being the radon decay constant noted as $\left(2.098 \times 10^{-6} \mathrm{~s}^{-1}\right)$, E being the scintillation efficiency ( $74 \%), \mathrm{V}$ being the water volume, $\mathrm{T}$ is the delay in counting after radon sampling and $\mathrm{t}$ being the duration for counting.

\section{Measurement of dose}

The sources of radon exposure to humans are mainly due to ingestion and inhalation. Ingestion dose depends upon the water consumed by humans per day. The annual effective dose for ingestion due to the radon in water was calculated by using the parameters suggested by [31].

$\mathrm{D}_{\operatorname{Ig}}\left(\mu \mathrm{Sv} \mathrm{y}^{-1}\right)=\mathrm{ARnW}_{\mathrm{R}} \times \mathrm{Cw}_{\mathrm{w}} \times \mathrm{EDC}$

Where, $D_{\mathrm{Ig}}$ is the effective ingestion dosage, $\mathrm{C}_{\mathrm{W}}$ is the water consumption weightage estimate by adult, children and babies as 730, 330 and $2301 \mathrm{y}^{-1}$ respectively [32], $\mathrm{A}_{\mathrm{RnW}}$ is the radon presence in water $\left(\mathrm{BqL}^{-1}\right.$ or $\left.\mathrm{kBqm}^{-3}\right)$ and $\mathrm{EDC}$ is the coefficient of effective dose for ingestion (3.5 nSv.Bq-1).

The radon present in the water can escape via indoor air during bath and other household utilities. Radon and its progeny when inhaled get trapped in lungs due to ionizing radiation gets penetrated in mucus membrane cells, bronchi and other pulmonary tissues causing lung cancer. The inhalation dose has been calculated by using the formula [31].

$\operatorname{Din}\left(\mu S v y^{-1}\right)=A_{R n W} \times C_{a W} \times F \times I \times D C F$

where, $D_{\text {In }}$ is the inhalation effective dose, $C_{a w}$ is ratio of air radon and water radon $\left(10^{-4}\right), A_{R n W}$ is the water radon concentration $\left(\mathrm{BqL}^{-1}\right.$ or $\left.\mathrm{kBq} \mathrm{m}^{-3}\right)$, I is the average residence time per individual $\left(7000 \mathrm{~h} \mathrm{y}^{-1}\right), \mathrm{F}$ being the radon and its progeny equilibrium factor (0.4) and DCF is the radon exposure dose conversion factor $\left[9 \mathrm{nSv}\left(\mathrm{Bqh} \mathrm{m}^{-3}\right)^{-1}\right.$ ]. The inhalation effective dose is expressed as micro sievert $(\mu \mathrm{Sv})$. The inhalation and ingestion to stomach and lung respectively were calculated by considering the tissue weighting factor for stomach (0.1196) and lung (0.1199) to the corresponding dose [33].

\section{Results and Discussion}

The statistical ${ }^{222} \mathrm{Rn}$ concentration is represented as box plot (Fig.2). Due to lesser samples in formations like cuddalore, kadaperikuppam and ootai limestone they were collective represented as Sandstone samples. The radon concentration in alluvium formation ranges between $0.13 \pm 0.01 \mathrm{BqL}^{-1}$ to $7.86 \pm 0.33 \mathrm{BqL}^{-1}$ with an average of $1.87 \pm 0.12 \mathrm{BqL}^{-1}$. In sandstone aquifer radon ranges between $1.51 \pm 0.23 \mathrm{BqL}^{-1}$ to $2.85 \pm 0.02 \mathrm{BqL}^{-1}$ with an average of $2.16 \pm 0.06 \mathrm{BqL}^{-1}$ and in Charnockite between $0.60 \pm 0.06$
$\mathrm{BqL}^{-1}$ to $1.54 \pm 0.12 \mathrm{BqL}^{-1}$ with an average of $0.96 \pm 0.09 \mathrm{BqL}$ 1 . The abundance of Rn varied significantly with reference to different litho units. Higher Radon observed in alluvium aquifer (7.86 $\mathrm{BqL}$ 1) followed by sandstone (2.85 $\mathrm{BqL} \sim 1$ ) and charnockite $\left(1.54 \mathrm{BqL}^{-1}\right)$. Lower $\mathrm{Rn}$ in Charnockite might be due to the lower $U$ observed in high pressure Archean Chanrockites [34] and factors like temperature and salinity that decrease radon solubility [35]. Increasing $\mathrm{Rn}$ along groundwater flow path with decreasing grain size in alluvium might be the reason for higher radon [35] and intermediate radon in sandstone might be due to long residence time and increasing temperature due to deeper aquifer condition [16]. The spatial variations attempted for ${ }^{222} \mathrm{Rn}$ in the study area demarcates higher ${ }^{222} \mathrm{Rn}$ in groundwater confined to locations like kurumpet and poyyapakkam noted along eastern and western parts of the study area and lower values were confined to a total of 14 locations (Fig.3). From the 14 a total of 3 samples (Aavadiyarpattu, Reddikuppam and Vidur) represent charnockite terrain along north western parts of the study area and rest of the samples represents alluvium formations. From the plot it is highly identical that ${ }^{222} \mathrm{Rn}$ release to the groundwater seems to be influenced by geological subsurface, radio nuclides dissolved in water and aquifer conditions. Excess radon in potable water raises serious health issues for which health and environmental protection agencies have recommended safe limits for human consumption. Safe limit of radon in drinking water for human consumption has been recommended by various environmental and health agencies. The United States Environmental Protection Agency [14] recommends $11.0 \mathrm{~Bq}$ $\mathrm{L}^{-1}$ as safe limit, United Nations Scientific Committee on the Effects of Atomic Radiation [31] suggests $4 \sim 40 \mathrm{Ba} \mathrm{L}{ }^{-1}$ as harmless, European Commission [12] and World Health Organisation [36] recommends $100 \mathrm{~Bq} \mathrm{~L}^{-1}$ as safe. The radon levels in groundwater samples irrespective of aquifers were well within the safe limits prescribed by various agencies might be due to absence of radon emanating minerals in the litho units of the aquifers and or aeration loss [37].

Annual effective dose of ingestion were calculated for babies, children and adults (Table 1) and the results ranges between $0.739 \mu \mathrm{Sv} \mathrm{y}^{-1}$ to $41.625 \mu \mathrm{Sv} \mathrm{y}^{-1}$ with an average of $9.507 \mu \mathrm{Sv} \mathrm{y}^{-1}$ for babies, $0.272 \mu \mathrm{Sv} \mathrm{y}^{-1}$ to $15.32 \mu \mathrm{Sv}$ $\mathrm{y}^{-1}$ with an average of $3.499 \mu \mathrm{Sv} \mathrm{y}^{-1}$ for children and 0.357 $\mu S v y^{-1}$ to $20.104 \mu S v y^{-1}$ with an average of $4.592 \mu S v y^{-1}$ for adult. Dose contribution from ingestion to lung ranges from $0.004 \mu \mathrm{Sv} \mathrm{y}^{-1}$ to $0.198 \mu \mathrm{Sv} \mathrm{y}^{-1}$ with an average of $0.0451 \mu \mathrm{Sv}$ $\mathrm{y}^{-1}$. The global average dose of radon ingestion is $0.025 \mathrm{~m} \mathrm{~Sv}$ $\mathrm{y}^{-1}$ [31] on comparison it was found that all the samples were within the limit.

Annual effective dose for inhalation calculated ranges between $0.352 \mu \mathrm{Sv}^{-1}$ to $19.829 \mu \mathrm{Sv} \mathrm{y}^{-1}$ with a mean of $4.529 \mu \mathrm{Sv}^{\sim}{ }^{-1}$ and dose contribution from the inhalation to 


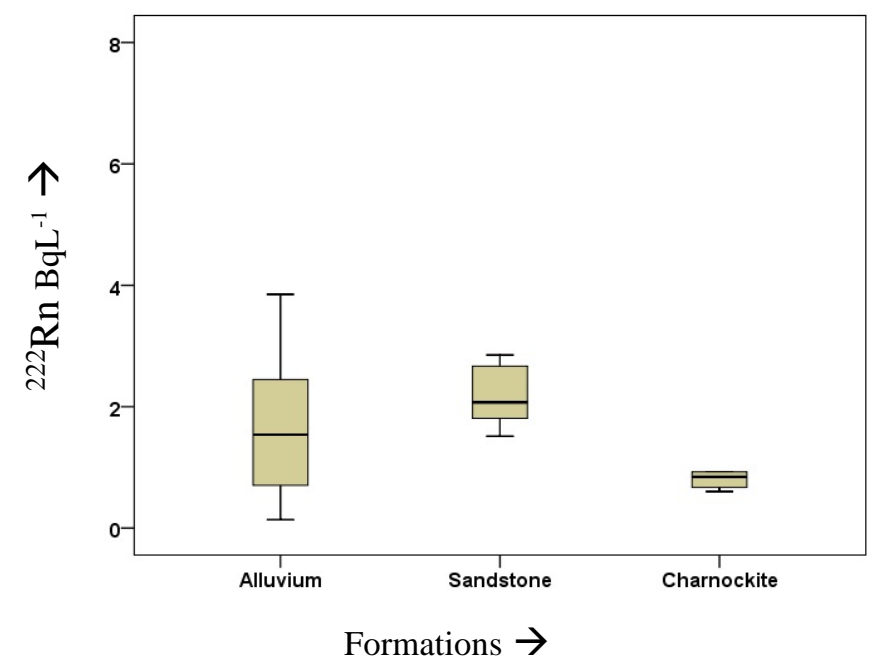

Fig 2. Statistical plot for Radon in study area in view of varying litho units.

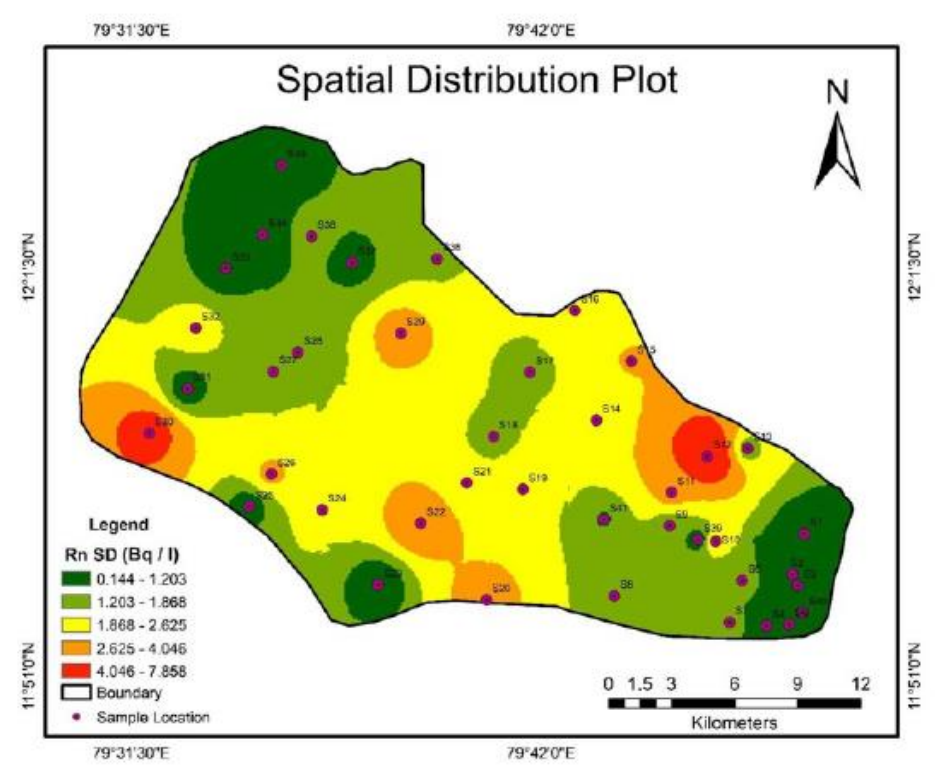

Fig 3. Spatial plot for Radon from the study area

stomach ranges between $0.042 \mu \mathrm{Sv} \mathrm{y}^{-1}$ to $2.377 \mu \mathrm{Sv} \mathrm{y}^{-1}$ with $613.98,734.52$ and $669.38, \mathrm{U}$ as $0.0020,0.4537$ and averages of $0.543 \mu \mathrm{Sv} \mathrm{y}^{-1}$. All the samples irrespective of litho 0.0054 and $\mathrm{Rn}$ as 2.00, 3.11 and 0.96 for alluvium, units were lower in comparison with global average Sandstone and charnockite aquifer respectively. Maximum inhalation does of $0.002 \mathrm{mSv} \mathrm{y}$ 1[36]. The total dose variation varied with reference to litho units might be due to calculated for adult ranges between $0.709 \mu \mathrm{Sv} \mathrm{y}^{-1}$ to 39.933 $\mu \mathrm{Sv} \mathrm{y}^{-1}$ with an average of $9.121 \mu \mathrm{Sv} \mathrm{y}^{-1}$ which is found to be below the prescribed limit $\left(1 \mathrm{mSvy}^{-1}\right)$ of [36].

Majority of water quality parameters represents minimal differences between the aquifer systems (Table 2). The mean EC values were 2149.5, 1530.0 and 2072.8, $\mathrm{pH}$ as 7.16, 6.97 and 7.33, salinity as 1254.69 , 980.75 and 1185.71, TDS as 746.88, 817.63 and 889.00, Eh as - 18.25, $\sim 18.03$ and 25.00 , DO as 4.71, 75.98 and 4.59, TH as 
Table1. Statistical Distribution of Radon concentration and corresponding doses

\begin{tabular}{|c|c|c|c|c|c|c|c|c|}
\hline & $\begin{array}{l}\text { Rn Conc. } \\
\left(B q L^{-1}\right)\end{array}$ & $\begin{array}{c}\mathrm{D}_{(\mathrm{ig})} \text { for } \\
\text { Babies } \\
\mu \mathrm{Svy}^{-1}\end{array}$ & $\begin{array}{c}\mathrm{D}_{(\mathrm{ig})} \text { for } \\
\text { children } \\
\mu \mathrm{Svy}^{-1}\end{array}$ & $\begin{array}{c}\mathrm{D}_{(\mathrm{ig})} \text { for } \\
\text { Adult } \\
\mu \mathrm{Svy}^{-1}\end{array}$ & $\begin{array}{c}\mathrm{D}_{\text {(Stomach) }} \\
\mu \mathrm{Svy}^{-1}\end{array}$ & $\begin{array}{c}D_{(\mathrm{in})} \\
\mu \mathrm{Svy}^{-1}\end{array}$ & $\begin{array}{l}D_{\text {(Lung) }} \\
\mu S y^{-1}\end{array}$ & $\begin{array}{c}\text { Total Dose } \\
\mu S v y^{-1}\end{array}$ \\
\hline Minimum & $0.140 \pm 0.01$ & 0.739 & 0.272 & 0.357 & 0.004 & 0.352 & 0.042 & 0.709 \\
\hline Maximum & $7.869 \pm 0.33$ & 41.625 & 15.320 & 20.104 & 0.198 & 19.829 & 2.377 & 39.933 \\
\hline Average & $1.797 \pm 0.12$ & 9.507 & 3.499 & 4.592 & 0.045 & 4.529 & 0.543 & 9.121 \\
\hline
\end{tabular}

Table $~ 2$ Statistical values of physicochemical parameters ( EC $\sim$ Electrical Conductivity ( $\mu$ s/cm), TDS Total Dissolved Solids (mg/l), SAL $\sim$ Salinity (mg/l), Eh Redox, DO Dissolved Oxygen (mg/l), TH Total hardness (mg/1), U Uranium (mg/1), Rn

Radon $(\mathrm{Bq} / 1)$.

\begin{tabular}{|c|c|c|c|c|c|c|c|c|c|}
\hline \multicolumn{10}{|c|}{ Alluvium } \\
\hline & $\mathrm{pH}$ & EC & TDS & SAL & Eh & DO & TH & $\mathrm{U}$ & Rn \\
\hline $\operatorname{Max}$ & 7.74 & 9860.00 & 1200.00 & 5670.00 & 18.00 & 7.90 & 1205.81 & 0.0040 & 7.87 \\
\hline Min & 6.53 & 349.00 & 204.00 & 200.00 & $\sim 50.00$ & 2.20 & 106.67 & 0.0010 & 0.14 \\
\hline Avg & 7.16 & 2149.59 & 746.88 & 1254.69 & $\sim 18.25$ & 4.71 & 613.98 & 0.0020 & 2.00 \\
\hline \multicolumn{10}{|c|}{ Sandstone } \\
\hline $\operatorname{Max}$ & 7.5 & 2460.00 & 1175.00 & 1440.00 & 5.40 & 290.00 & 1113.76 & 1.8079 & 6.09 \\
\hline Min & 6.09 & 290.00 & 290.00 & 498.00 & $\sim 40.00$ & 4.40 & 203.91 & 0.0020 & 1.51 \\
\hline Avg & 6.97 & 1530.00 & 817.63 & 980.75 & 18.03 & 75.98 & 734.52 & 0.4537 & 3.11 \\
\hline \multicolumn{10}{|c|}{ Charnockite } \\
\hline $\operatorname{Max}$ & 7.45 & 2970.00 & 960.00 & 1700.00 & $\sim 17.00$ & 4.80 & 821.02 & 0.0060 & 1.54 \\
\hline Min & 7.21 & 1350.00 & 790.00 & 770.00 & -32.00 & 4.30 & 566.29 & 0.0040 & 0.60 \\
\hline Avg & 7.33 & 2072.86 & 889.00 & 1185.71 & -25.00 & 4.59 & 669.38 & 0.0054 & 0.96 \\
\hline
\end{tabular}

\section{Saturation index}

The saturation index is a measure of particular mineral system's tendency to precipitate or dissolve in the groundwater. PHREEQC geochemical code suggested by [42] has been attempted for the present study to isolate the uranium solubility and its interactions within the aquifers systems of the study area. The saturation index (SI) of groundwater samples expressed in view of its mineral precipitation is expressed as:

$$
\mathrm{SI}=\log (\mathrm{IAP} / \mathrm{Ksp})
$$

The IAP represents the ion activity of the solution; Ksp indicates the equilibrium constant of the reaction in view of temperature (T) [43]. The solubility of chemical species is attempted by calculating the SI of the minerals that could either precipitate or dissolved in the aquifer system due to varying ionic activities of the chemical species. If the water is in equilibrium with the dissolved mineral, SI will tend to be zero, positive values indicate saturation and negative indicate under saturation [44]. Uranium in groundwater is influenced by oxidation and decay of uranium in groundwater. Uranium strongly bonds with oxygen in water and forms soluble oxyions. In highly acidic to reducing environment uranous cation $\left(\mathrm{U}^{4+}\right)$ is formed which generally forms hydroxide complexes (e.g., $\mathrm{UOH}^{3+}$, $\left.\mathrm{U}(\mathrm{OH})_{4}\right)$ and under highly oxidising environment $\mathrm{U}^{6+}$ occurs as Uranyl ion $\left(\mathrm{UO}^{2+}\right)$. Due to the soluble complex formation of uranim, U6 is more mobile in groundwater environment in comparison with other uranium valancies [45].

A total of 8 uranium mineral species were isolated from the saturation index calculation of mineral phases such as coffinite $\left(\mathrm{USiO}_{4}\right)$, Haiweeite $\left(\mathrm{Ca}\left(\mathrm{UO}_{2}\right) 2\left(\mathrm{Si}_{2} \mathrm{O}_{5}\right) 3: 5 \mathrm{H}_{2} \mathrm{O}\right)$, Rutherfordine $\left(\mathrm{UO}_{2} \mathrm{CO}_{3}\right)$, Schoepite $\left(\mathrm{UO}_{2}(\mathrm{OH})_{2}: \mathrm{H}_{2} \mathrm{O}\right)$, Sklodowskite $\left.\mathrm{Mg}\left(\mathrm{H}_{3} \mathrm{O}\right) 2\left(\mathrm{UO}_{2}\right)_{2} \quad\left(\mathrm{SiO}_{4}\right) 2: 4 \mathrm{H}_{2} \mathrm{O}\right)$, Soddyite $\left.\left.\mathrm{UO}_{2}\right) 2 \mathrm{SiO}_{4}: 2 \mathrm{H}_{2} \mathrm{O}\right)$, Uraninite $\left(\mathrm{UO}_{2}\right)$ and Uranophane $\left(\mathrm{Ca}\left(\mathrm{UO}_{2}\right)_{2}\left(\mathrm{SiO}_{3} \mathrm{OH}\right) 2 \cdot 5 \mathrm{H}_{2} \mathrm{O}\right)$ (Table 3 \& Fig. 4). 
Table 3. Saturation index of Uranium mineral species from the study area

\begin{tabular}{|c|c|c|c|c|c|c|c|c|}
\hline & Coffinite & Haiweeite & Rutherfordine & Schoepite & Sklodowskite & Soddyite & Uraninite & Uranophane \\
\hline Min & $\sim 9.46$ & $\sim 4.93$ & $\sim 5.71$ & $\sim 4.52$ & $\sim 9.13$ & $\sim 3.44$ & $\sim 8.67$ & $\sim 10.55$ \\
\hline Max & $\sim 5.18$ & 1.43 & $\sim 3.39$ & $\sim 2.9$ & $\sim 5.25$ & $\sim 0.09$ & $\sim 4.44$ & $\sim 8.64$ \\
\hline Avg & $\sim 7.71$ & $\sim 1.51$ & $\sim 4.81$ & $\sim 3.59$ & $\sim 7.17$ & $\sim 1.66$ & $\sim 7.19$ & $\sim 9.96$ \\
\hline
\end{tabular}

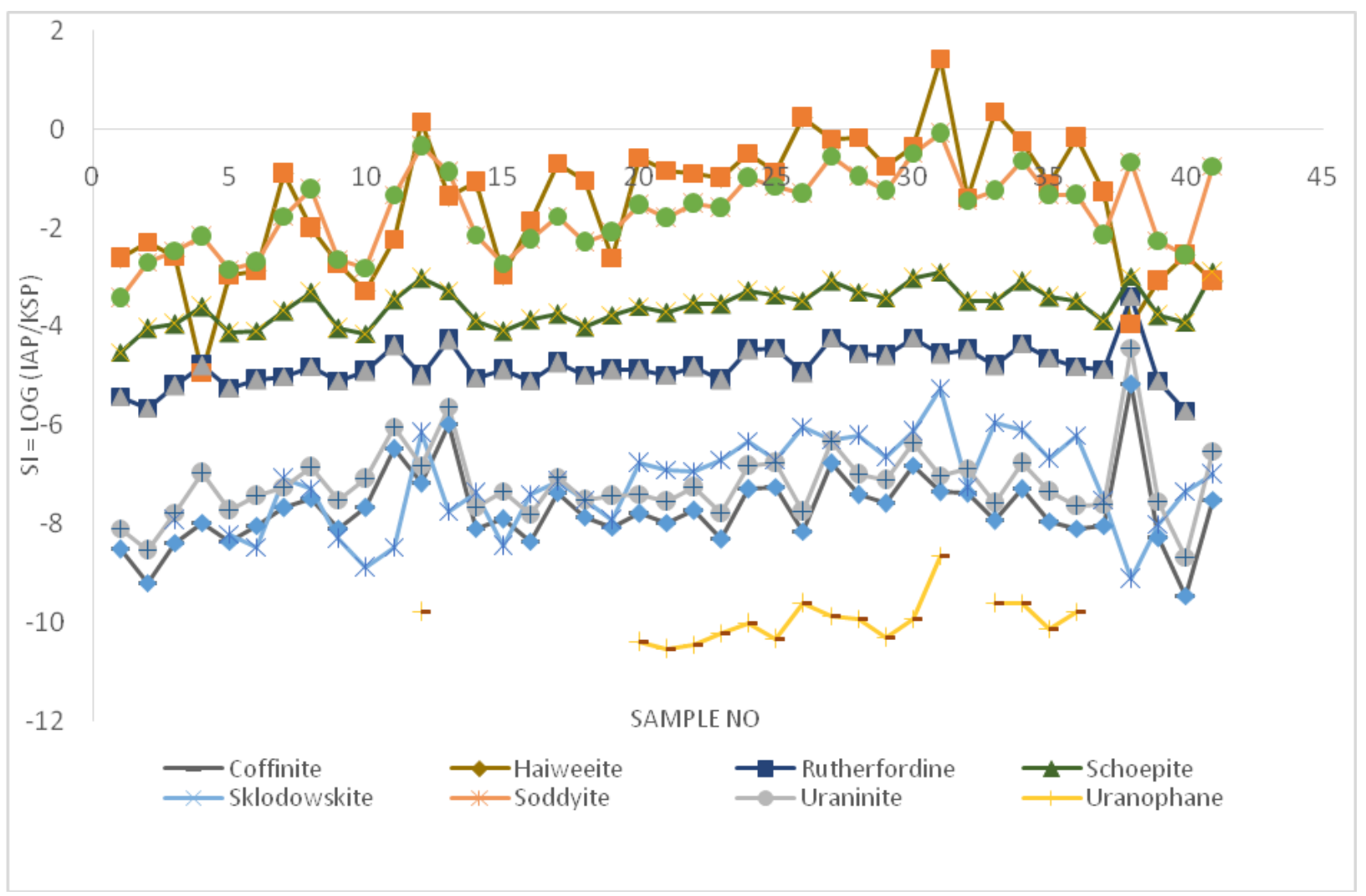

Fig.4 Abundance of Uranium mineral species with reference to samples

All the minerals species except Haiweeite and Soddyite are states are more stable when compared with III and V that are found to be undersaturated indicating dissolving phase. transitory. The difference in oxidation states between VI and Locations like Kurumpet (0.15), Nilangadu (0.22), IV determines the occurrence of uranium in the aqueous. Kappiyapuliur (1.43) and Avadiyarpattu (0.36) has positive solution, whether to be sorbed, mobilized, precipitated or SI values which means nearly precipitation. All other species immobilized[47].

shows dissolution (negative SI).

\section{Uranium species in $\mathrm{Eh} \sim \mathrm{pH}$ condition}

The Eh $\sim \mathrm{H}$ diagram is generally used to isolate the mineral stability field that controls the geochemistry of groundwater. The solubility of uranium in groundwater system is influenced by factors like: redox potential (Eh), hydrogen ion concentration $(\mathrm{pH})$ and dissolved carbonate [46]. The existence of uranium in groundwater system is predominately as III, IV, V and VI oxidation states. But in natural environmental conditions the IV and VI oxidation
The solubility of uraninite varies with degree of oxidation and changes in redox conditions. Under lower Eh uraninite is stable between $\mathrm{pH}$ ranges 2 and 8 and above $\mathrm{pH}$ 5 , U (VI) Occurs as aquocomplexes in natural waters [48, 49]. The Eh $\sim \mathrm{pH}$ diagram (Fig.5) attempted for the present study depicts acidic to alkaline $\mathrm{pH}$ of samples indicating oxidizing environment that increases the solubility of uranium favouring formation of soluble complexes [50]. This positive environment infers groundwater soluble in $\mathrm{U}_{4} \mathrm{O}_{9}(\mathrm{cr})$ (Uraninite) species. 


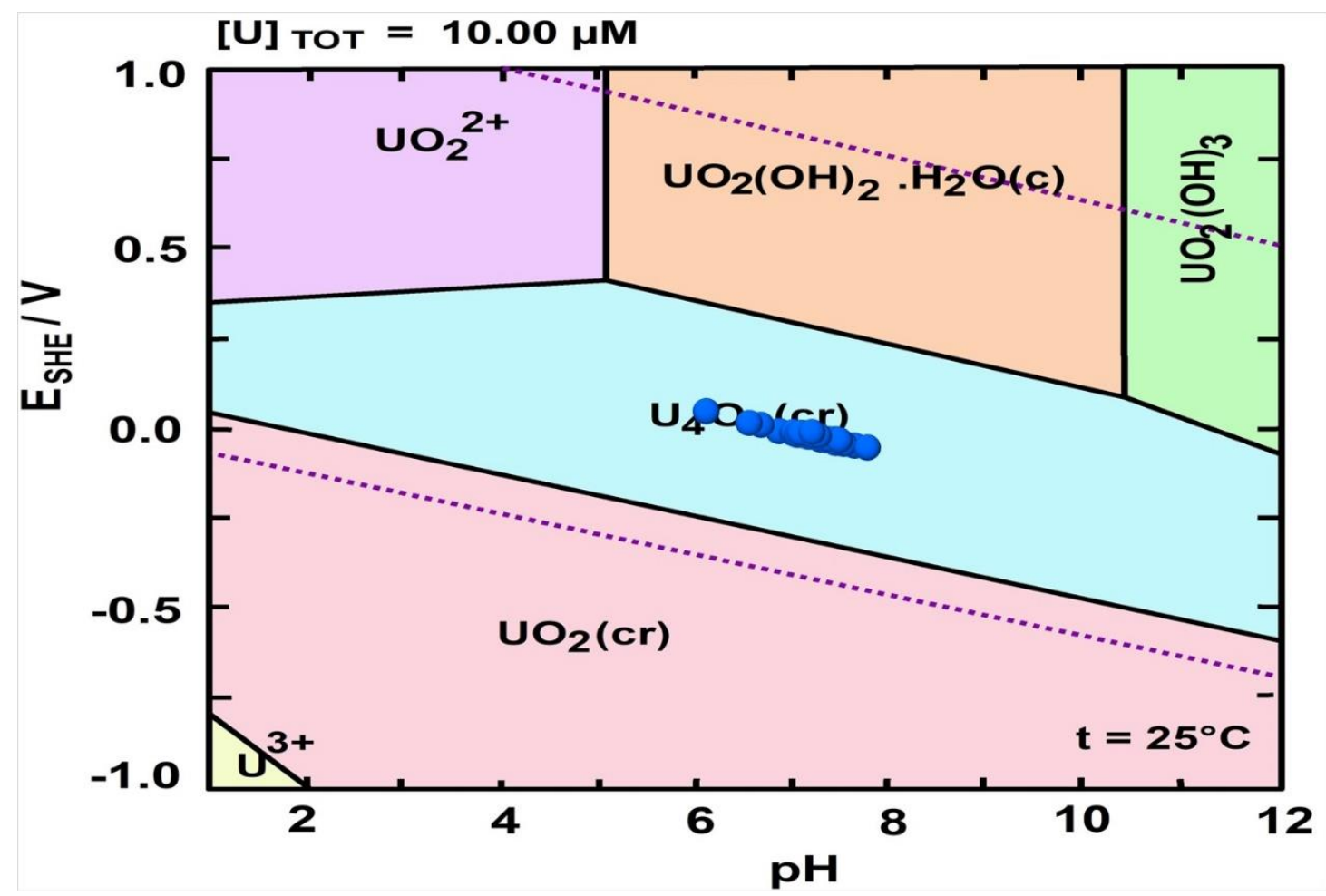

Fig 5. Eh $\sim \mathrm{pH}$ diagram for groundwater samples from the study area

\section{Conclusions}

1. This study investigated, Radon $\left.{ }^{222} \mathrm{Rn}\right)$ present in the ground water in Sankarabarani river sub basin has found below the maximum contamination level of 11.1 $\mathrm{BqL}^{-1}$ by EPA's. It is found that extra risk of getting cancer from this exposure comes out to be nearly 2 in 100000 which can be designated as minimal risk.

2. The variation in radon irrespective of litho units might be due to variation of lithology, uranium content, aquifer depth, hydrogeological and aquifer properties.

3. Annual effective dose due to the ingestion and inhalation were lower than recommended limit for the public of $100 \mu \mathrm{Svy}^{-1}$ prescribed by the UNSCEAR and WHO.

4. Isolating radon sources to the groundwater enrivonment attempted using uranium speciation suggests all uranium species undersaturated except Haiweeite and Soddyite showing nearly saturated suggesting possible sources for uranium/radon to the groundwater environment.

5. The Eh $\sim \mathrm{pH}$ diagram infers groundwater is soluble with respect to $\mathrm{U}_{4} \mathrm{O}_{9}$ species (uraninite) within the $\mathrm{pH}$ range of 6 to 8

\section{References}

[1] Lee, R. W., and Strickland, D. J. ( 1988), Geochemistry of ground water in tertiary and cretaceous sediments of the southeastern coastal plain in eastern Georgia, South Carolina, and southeastern North Carolina, Water
Resour. Res., 24( 2), 291- 303, doi:10.1029/WR024i002p00291

[2] Gopal Krishan, Rao MS, Kumar CP (2015) Estimation of radon concentration in groundwater of coastal area in Baleshwar district of Odisha, India, Indoor and Built Environment, vol. 24, 8: pp. 1147 1152.

[3] Fonollosa, E., Penalver, A., Borrull, F., Aguilar, C., 2016. Radon in spring waters in the south of Catalonia. J. Environ. Radioact. 151, 275e281.

[4] Abbady, A., Abbady, A.G.E. and Michel, R. (2004) Indoor radon measurement with The Lucas cell technique. Applied Radiation and Isotopes, 61, 1469 1475. doi:10.1016/j.apradiso.2004.03.065.

[5] Rasouli J, Khosravi SM. The role of radon in drinking water pollution in Bukan (North West Iran). Material Sci \& Eng. 2018;2(6):252-256. DOI: 10.15406/mseij.2018.02.00066

[6] Jobbágy, V., Altzitzoglou, T., Mayo, P., Tanner, V., Hult, M., 2017. A brief overview of radon measurements in drinking water. J. Environ. Radioact. 173, 18-24.

[7] Prakash R, Srinivasamoorthy K, Gopinath S, Saravanan K, Vinnarasi F, Ponnumani G, Chidambaram S, Anandhan P (2018) Radon isotope assessment of submarine groundwater discharge (SGD) in Coleroon River Estuary, Tamil Nadu, India J Radioanal Nucl Chem 317: 25. https://doi.org/10.1007/s10967 018 5877 2 
[8] Wu, Y.Y., Ma, YZ., Cui, HX., Liu, J., Sun, YR., Shang, B., (2014). Radon concentrations in drinking water in beijing city, China and contribution to radiation dose. Int J Env Res and Pub health, 11121e11131.

[9] Gunderson CS and Wanty RB (1993). Field Studies of Radon in Rocks, Soils and Water. CRC Press, BocaRaton, Florida.

[10]Gert Knutsson and Bo Olofsson (2002) Radon content in groundwater from drilled wells in the Stockholm region of Sweden, National Geophysical Union, 439, pp.79

[11]Christopher P. Cameron (1987) A review of Radon emanation and mobilization in minerals and rocks, Department of the Army, US Army Corps of Engineers, Washington, DC 20314 1000, Miscellaneous Paper, GL $87 \sim 27$.

[12] European Commission (1998) European drinking water directive 98/83/EC of 3rd November 1998 on the quality of water intended for human consumption, Official Journal of the European Commission. 330

[13]National Research Council (1999) Health Effects of Exposure to Radon, BEIR VI, Washington (DC): National Academies Press (US), ISBN 10: 0 309 05645 4.

[14]USEPA (1999) Radon in drinking water health risk reduction and cost analysis. Fed Reg 64(38):9560-9599

[15] WHO World health organization. (2004). Guidelines for drinking water quality. Radiological aspects (3rd, Vol. 1, pp. 1e494). Geneva: world health organization

[16]Duggal, V., Sharma, S., Srivastava, A.K. et al. J Geol Soc India (2018) 91: 700. https://doi.org/10.1007/s12594 018 0926 6

[17] Srinivasamoorthy K, Ponnumani G, Prakash R, Gopinath S, Saravanan K, Vinnarasi F (2018) Tracing groundwater inputs to Bay of Bengal from Sankarabarani River Basin, Pondicherry, India, using continuous radon monitoring. International Journal of Environmental Science and Technology. doi:10.1007/s13762 018 1938 X

[18]Central Groundwater board, Ground water brochure, Puducherry Region Union Territory of Puducherry, Technical Report Series, SECR/DBR/UT/12 13/01 27 (2007).

[19]Elliot T, Bonotto DM, Andrew JN (2014) Dissolved uranium, radium and radon evolution in the Continental Intercalaire aquifer, Algeria and Tunisia, Journal of Environmental Radioactivity 137 (2014) 150e162.

[20] Shilpa GM, Anandaram BM, Mohankumari TL (2017) Measurement of 222Rn concentration in drinking water in the environs of Thirthahalli taluk, Karnataka, India Journal of Radiation Research and Applied Sciences 10 (2017) 262e268

[21] Przylibski TA (2008) Size estimation and protection of the areas supplying radon to groundwater intakes, Archives of Environmental Protection 26(1):55 71

[22] Ravikumar, P., Davis, D., Mathew, S. (2014) Spatio temporal variation in radon concentration in groundwater with respect to rock types: A case study from Chitradurga district, Karnataka, J Geol Soc India (2014) 83: 156. https://doi.org/10.1007/s12594 014 0027 0

[23] King, P.T., Michel, Jacqueline, and Moore, W.S., 1982, Ground water geochemistry of $\mathrm{Ra} \sim 228, \mathrm{Ra} \sim 226$, and $\mathrm{Rn} \sim$ 222: Geochimica et Cosmochimica Acta, v. 46, p. 1173 1182

[24]Vinson, D S, Vengosh, A, Hirschfeld, D, Dwyer, GS ( 2009) Relationships between radium and radon occurrence and hydrochemistry in fresh groundwater from fractured crystalline rocks, North Carolina (USA). Chem Geol, 260, 159- 71.

[25] Najeeb K, Vinayachandran N, Bijimol Jose and Rahulvashistha (2014) Radon in Groundwater in Tumkur District of Karnatakawith Special Reference to Sampling Sensitivity, Journal of Geological Society of India, Vol.83, pp.665 668

[26] Gopinath S, Srinivasamoorthy K, Vasanthavigar M, Saravanan K, Prakash R, Suma CS Senthilnathan D (2016b) Hydrochemical characteristics and salinity of groundwater in parts of Nagapattinam district of Tamil Nadu and the Union Territory of Puducherry. India Carbonates Evaporites, DOI: 10.1007/s13146 016 0300 y

[27]Eappen. K. P., Nair. R. N., Mayya. Y. S., 2008, Simultaneous measurement of radon and thoron using Lucas scintillation cell, radiation measurement 43 (2009) 91 97

[28]Vandilla. M. A., Taysum. D. H., 1999 Scintillation counter for assay of radon gas Nucleonics 13, 68

[29] Lucas. H. F., 1957. Improved low level alpha scintillation counter for radon. Rev. Sci. Instum 28, 680.

[30] Raghavayya M, Iyengar MAR, Markose PM (1980) Estimation of ${ }^{226} \mathrm{Ra}$ by emanometry. Bull RadiatProt 3(4):11-14

[31]UNSCEAR (2000) Report to the general assembly with scientific annexes. United Nations, Annexure B, New York, pp 97-105

[32] UNSCEAR (1993) United Nations Scientific Committee on the Effects of Atomic Radiation. Sources and Effects of 
Ionizing Radiation. Annex A: Exposure from Natural Sources of Radiation. UNSCEAR 1993 Report to the General Assembly, with Scientific Annexes. United Nations.

[33]Darby, S., Hill, D., Auvinen, A., Barros Dios, J., Baysson, H., Bochicchio, F., \&Hakama, M. (2005). Radon in homes and risk of lung cancer: collaborative analysis of individual data from 13 European case control studies. British Medical Journal, 330(7485), 223.

[34]Condie K.C and Allen P (1984) Origin of Archean chamockites from southern India. In Archaean Geochemistry eds. A. Kroner, A.M.Goodwin and G.M.Hanson, Springer Verlag, Berlin.

[35] Gorgoni, C \& Martinelli, Giovanni \& Sighinolfi, Giampaolo. (1982). Radon distribution in groundwater of the Po sedimentary basin (Italy). Chemical Geology. 35. 297 309. 10.1016/0009 2541(82)90007 9.

[36] WHO World Health Organization. Handbook on indoor radon: A public perspective. Zeeb $\mathrm{H}$, Shannoun F, ed. Geneva, Switzerland: WHO Press; (2009). Available at http://apps.who.int/iris/ itstream/10665/44149/1/ 9789241547673_eng.pdf. Volume 8, Issue 3, July 2015, Pages 294 299

[37] NisarAhmad, Mohamad Suhaimi , Jaafar Mohammed Saad Alsaffar (2015) Study of radon concentration and toxic elements in drinking and irrigated water and its implications in Sungai Petani, Kedah, Malaysia, Journal of Radiation Research and Applied Sciences

[38] Gopinath S, Srinivasamoorthy K, Saravanan K, Suma CS, Prakash R, Senthilnathan D, Chandrasekaran N, Srinivas Y, Sarma VS (2016a) Modeling saline water intrusion in Nagapattinam coastal aquifers, Tamilnadu, India. Model Earth Syst Environ 2:2. http s://doi.org/10.1007/s408 08 015 0058 6

[39] Prakash R, Srinivasamoorthy K, Gopinath S, Saravanan K (2018a) Measurement of submarine groundwater discharge using diverse methods in Coleroon Estuary, Tamil Nadu, India. Appl Water Sci 8:13. https://doi.org/10.1007/s13201 018 0659 0.

[40]K. Saravanan, K. Srinivasamoorthy, S. Gopinath, R. Prakash, C. S. Suma, J. Vinnarasi and G. Ponnumani (2018) Geochemical evolution of groundwater along flow path in Upper Vellar sub basin, Tamilnadu, India: an integrated approach using hydrochemistry, modeling and statistical techniques. Modeling Earth Systems and Environment DOI:10.1007/s40808 017 0400 2.

[41]R. Prakash, K. Srinivasamoorthy, S. Gopinath and K. Saravanan (2017) Preliminary Study on the Decadal Changes in Temperature and Rainfall on the Hydrochemistry of Surface and Groundwater in
Coleroon River Estuarine Zone, East Coast of India. Journal of climate change $3: 2$ DOI :10.3233/JCC 170013.

[42] Parkhurst DL, Appelo CAJ (2013) Description of input and examples for PHREEQC version 3-a computer program for speciation, batchreaction, one dimensional transport, and inverse geochemical calculations. US Geological Survey Techniques and Methods, book 6,chap A43:497

[43] Lee RW, Strickland DJ (1988) Geochemistry of ground water in tertiary and cretaceous sediments of the southeastern coastal plain in eastern Georgia, SouthCarolina, and southeastern North Carolina.Water Re -Sources Research 24(2):291-303

[44]Appelo CAJ, Postma D (1996) Geochemistry, groundwater, and pollution.Balk, Rotterdam, p. 536.

[45] Saunders, J.A., Pivetz, B.E., Voorhies, N., Wilkin, R.T., 2016.Potential aquifer vulnerability in regions down gradient from uranium in situ recovery (ISR) sites. J. Environ.Manag. 183, 67-83.

[46] Murphy WM, Shock EL (1999) Mineralogical Society of America. In: Burns PC, Finch R (eds) Environmental aqueous geochemistry of actinides. Uranium: mineralogy, geochemistry and the environment, vol 38, pp. 221-254

[47] Meinrath G (1998) Aquatic chemistry of uranium-a review focusing on aspects of environmental chemistry. FOG, ISSN 1434-7512(http://www.geo.tu freiberg.de/fog), 1:1-99

[48]Langmuir DL (1997) Aqueous environmental geochemistry. Prentice Hall, New Jersey, p 168

[49]CS Suma, K Srinivasamoorthy , K .Saravanan S. Gopinath, R. Prakash and A FaizalKhan (2016) The geochemistry of uranium occurrences and speciation in groundwater of Chinnar sub basin, South India. Arabian Journal of Geoscience 9:703.DOI 10.1007/s12517 016 2642 0.

[50]Hamutoko, JT; Mapani, BS; Ellmies, R; Bittner, A; Kuells, $\mathrm{C}$ (2014) A fingerprinting method for the identification of uranium sources in alluvial aquifers: An example from the Khan and Swakop Rivers, Namibia, Physics and Chemistry of the Earth, Parts A/B/C, Volume 72 75, PP 34 42, DOI 10.1016/j.pce.2014.09.006 .

\section{Acknowledgement}

The corresponding author acknowledges Department of Science and Technology, Science and Engineering Research Board for financial grant (Grant No. EMR/2015/001101), India. The authors thank their lab colleagues and students for their help rendered during sample collection and analysis. 


\section{About The License}

(C) 2019 The Authors. This work is licensed under a Creative Commons Attribution 4.0 International License which permits unrestricted use, provided the original author and source are credited. 